\title{
SPECIALIZED EXTRUSION PRODUCTS FOR PREGNANT AND LACTATING WOMEN AND THEIR BIOLOGICAL STUDIES
}

\author{
N. Laptenok \\ State enterprise "Beltekhnokhleb", Minsk, Republic of Belarus \\ E. Tumar, V. Laptsevich \\ Institute of Bioorganic chemistry of NAS of Belarus, Minsk, Republic of Belarus \\ L. Melnikova \\ Belarusian state University of Economics
}

\begin{abstract}
Key words:
extrusion products, glycemic index, nutrition of pregnant women

Article history:

Received 16.10.2019

Received in revised form

15.11.2019

Accepted 25.11.2019

Corresponding author:

laptenokn@mail.ru

ABSTRACT

The diet of a pregnant and lactating woman should meet her physiological needs. A variant of rationalization of nutrition of pregnant and lactating women is the use of specialized foods enriched with protein, vitamins and minerals, in order to correct eating disorders, creating diets balanced by most nutritional factors .

Justification of recipes and technology of production of food products for specialized purposes is an urgent task, the solution of which can make a certain contribution to the rehabilitation of the population. This problem can be solved by using inulin, pectin substances, dietary fibers, vitamins, macro -, microelements, balanced proteins with appropriate functional properties and obtained from various types of vegetable materials.

The purpose of this work was to study the effect on the body of laboratory animals of eating specialized extrusion products for pregnant and lactating women, developed by the State enterprise "Beltekhnokhleb", to assess their safety and effectiveness.

Samples of specialized extrusion products were studied: calcium-enriched extrusion loaves, salt-free extrusion loaves and inulin extrusion loaves, which were introduced into the diet of both non-pregnant and pregnant Wistar female rats.

Morphometric parameters (dynamics of body weight, absolute and relative weight of organs), hematological and biochemical parameters at day 30 of extrusion products consumption were evaluated in animals and their glycemic index was determined by day 15 of observation (second half of pregnancy).

The obtained data allow us to evaluate the studied extrusion products as safe and recommend extrusion loaves enriched with calcium, salt-free extrusion loaves and extrusion loaves with inulin, having a low glycemic index, for dietary nutrition of both pregnant and lactating women, and for other categories of the population.
\end{abstract}

DOI: $10.24263 / 2225-2916-2019-26-10$

(C) Н. С. Лаптенок, Е. М. Тумар, В. В. Лапцевич, Л. А. Мельникова, 2019 


\title{
БІОЛОГІЧНІ ДОСЛІДЖЕННЯ СПЕЦІАЛІЗОВАНИХ ЕКСТРУЗІЙНИХ ПРОДУКТІВ ДЛЯ ВАГІТНИХ І ЖІНОК-ГОДУВАЛЬНИЦЬ
}

\author{
Н. С. Лаптенок \\ Державне підприємство «Белтехнохлеб», м. Мінськ, Республіка Білорусь \\ Е. М. Тумар, ст. н. с. \\ В. В. Лапцевич, м. н. с. \\ Інститут біоорганічної хімії НАН Білорусі, м. Мінськ, Республіка Білорусь \\ Л. А. Мельникова, канд. біол. наук \\ УО «Білоруський державний економічний університет», м. Мінськ, Республіка \\ Білорусь
}

У статmі розглянуто важливість спеціалізованого харчування для здоров'я вагітних і жінок-годувальниць та наведено результати досліджень впливу нових видів екструзійних виробів на організм вагітних і невагітних щурів. Вивчення гематологічних і біохімічних параметрів, глікемічного індексу показало безпеку і ефективність використовуваних продуктів.

Ключові слова: екструзійні продукти, глікемічний індекс, харчування вагітних жінок.

Постановка проблеми. Харчування - найважливіший фактор зовнішнього середовища, який визначає правильний розвиток, стан здоров’я і працездатність людини [1]. В останні роки намітилася стійка тенденція до використання харчування для профілактики і лікування. У світовому масштабі йде постійна робота зі створення нових продуктів функціонального харчування, що володіють як широким спектром застосування, так і вузькою спрямованістю на конкретний орган, систему, захворювання.

Раціональне харчування є одним з важливих умов сприятливого перебігу і результату вагітності, пологів, розвитку плода і новонародженого. Харчовий раціон вагітної і жінки-годувальниці повинен відповідати ії фізіологічним потребам.

Варіантом раціоналізації харчування вагітних i жінок-годувальниць $є$ використання спеціалізованих харчових продуктів, збагачених білком, вітамінами і мінеральними речовинами, з метою корекції порушень харчування, створення раціонів, збалансованих за більшістю харчових факторів [2; 3].

Розробка спеціалізованих продуктів, у тому числі для цієї категорії населення, - один з основних векторів реалізації Державної політики у сфері здорового харчування і збереження здоров'я населення Республіки Білорусь [4].

Основні гігієнічні принципи розробки спеціалізованих продуктів для вагітних і жінок-годувальниць стосуються:

- забезпечення необхідної, науково обгрунтованої харчової та енергетичної цінності готової продукції відповідно до фізіологічних особливостей організму;

- використання сировини та компонентів, допущених для використання у зазначених продуктах;

- забезпечення гігієнічної безпеки продовольчої сировини, компонентів і готової продукції.

Обгрунтування рецептур і технології виробництва харчових продуктів спеціалізованого призначення $\epsilon$ актуальним завданням, вирішення якого здатне внести певний внесок в оздоровлення населення. Ця задача може бути вирішена шляхом 
використання інуліну, пектинових речовин, харчових волокон, вітамінів, макро-, мікроелементів, збалансованих білків, що володіють відповідними функціональними властивостями.

Мета дослідження: вивчення впливу на організм лабораторних тварин спеціалізованих екструзійних продуктів, розроблених Державним підприємством «Белтехнохлеб», 3 метою оцінки їх безпеки та ефективності для вагітних і жінокгодувальниць.

Матеріали і методи. Робота виконувалася як на невагітних, так і на вагітних щурах-самицях Wistar $(\mathrm{n}=40)$ у віці 3 місяців середньою масою 200-250 г, що містилися в контрольованих умовах навколишнього середовища $\left(18-22^{\circ} \mathrm{C}\right.$ і відносній вологості повітря 50-70\%) зі світловим режимом 12 годин світла і 12 годин темряви і режимом провітрювання, що забезпечує зміну 15 обсягів приміщення в годину в клітках по 5 осіб в кожній.

Досліджувалися зразки спеціалізованих екструзійних продуктів для вагітних $\mathrm{i}$ жінок-годувальниць: хлібці екструзій ні, збагачені кальцієм (хлібці 1), хлібці екструзійні безсольові (хлібці 2) і хлібці екструзійні з інуліном (хлібці 3), які вводили в раціон щурів, як замінники батона, доза якого на невагітну самицю становить 8 г/особину, на вагітну або годуючу самицю - 12 г/особина протягом 30 діб.

У тварин оцінювалися морфометричні параметри: динаміка маси тіла, абсолютна і відносна маси органів. Тварини зважували на вагах Scout Pro моделі SPU202. Виділялися такі органи: серце, селезінка, нирки, печінка. Органи зважували на електронних вагах Explorer моделі ЕР214. Вагові індекси органів розраховувалися як відношення маси органів до маси тіла тварин у відсотках. Відносні коефіцієнти маси (ВКМ) внутрішніх органів розраховувалися за виразом [5]:

$$
\text { ВМК }=\frac{\text { маса органу }}{\text { маса тварини }} \cdot 100 .
$$

На 15 добу експерименту (друга половина вагітності) у тварин всіх груп визначався глікемічний індекс розроблених продуктів харчування [6]. Для цього після 18годинної харчової депривації визначали концентрацію глюкози в крові, потім протягом 30 хв тваринам згодовувалися досліджувані зразки при вільному доступі (3 розрахунку 30 г на особину).

Забір крові здійснювався через 30, 60, 90 і 120 хв індивідуально з бічної хвостової вени. Рівень глюкози вимірювався за допомогою глюкометра «Fine-Test» (Корея). Розрахунок площ під глікемічними кривими, отриманими в ході досліджень, проводився за загальноприйнятою методикою з використанням такої формули:

$[(\mathrm{A}+\mathrm{B} / 2) * \mathrm{t}]+[(\mathrm{B}+\mathrm{C}) * \mathrm{~T} / 2]+[(\mathrm{C}+\mathrm{D}) * \mathrm{~T} / 2]-$ якщо остання точка глікемії $(120 \mathrm{xB})$ розташовувалася вище за базальний рівень;

A, B, C, D - приріст глюкози крові, тобто різниця між іï базальним рівнем i змістом у досліджені проміжки часу $(\mathrm{t}, \mathrm{T})[6]$.

На підставі отриманих даних розраховувався глікемічний індекс розроблених продуктів харчування.

На 30 добу експерименту, після евтаназії і забору крові, досліджувалися гематологічні та біохімічні параметри. Аналіз показників цільної крові здійснювався на гематологічному аналізаторі «Нumacaunt» (Німеччина), а біохімічних показників сироватки крові - на автоматичному аналізаторі «Hitachi-902» (Швейцарія) за допомогою наборів реагентів «Р. Z. Company» (Польща). 
Статистична обробка проводилася з використанням пакета аналізу даних Excel. Для кожної групи обчислювалося середнє значення (M), стандартне відхилення (SD). Достовірність оцінювалася за критерієм t-Стьюдента 3 урахуванням дисперсії (F-тест), параметричного статистичного методу за допомогою програми Statistica 6,0. Відмінності вважалися достовірними при $\mathrm{p}<0,05$.

Результати досліджень. Результати досліджень стану фактичного харчування жінок фертильного віку, вагітних і жінок-годувальниць, забезпеченості їх організму харчовими речовинами, свідчать про те, що раціони значної частини жінок характеризуються недостатньою енергетичною цінністю, зниженим вмістом загальних білків (в тому числі тваринного походження), рослинних жирів, вуглеводів, вітамінів А (в ретиноловому еквіваленті), С, вітамінів групи В, кальцію, магнію, заліза, інших мікронутрієнтів порівняно з рекомендованими рівнями.

Світовий досвід підтверджує, що вживання спеціалізованих харчових продуктів відіграє важливу роль в оптимізації харчування вагітних і жінок-годувальниць, сприяє збереженню здоров'я матері і дитини.

У Республіці Білорусь, як і в інших країнах, виробництво спеціалізованих хлібобулочних виробів для харчування вагітних і жінок-годувальниць, яке дає змогу проводити адекватну корекцію наявних порушень структури харчування і дисбалансу харчових речовин в раціоні, є сьогодні актуальним завданням.

Хлібобулочні вироби, незважаючи на відносне зниження їх споживання, займають важливе місце в раціоні більшості населення.

У зв'язку з цим фахівцями Державного підприємства «Белтехнохлеб» розроблена лінійка хлібців екструзійних «Мамин вибір» для харчування вагітних і жінокгодувальниць, з більш жорсткими вимогами до інгредієнтного складу і харчової цінності: без додавання кухонної солі або зі зниженим вмістом кухонної солі, цукру; виключення облігатних алергенів, спецій, консервантів, синтетичних барвників, ароматизаторів, кондитерських жирів, маргаринів, у складі яких можуть бути транс-ізомери жирних кислот; використання тільки дозволених у дитячому харчуванні харчових добавок; збільшеного вмісту харчових волокон, кальцію.

Проведено біологічні дослідження розроблених екструзійних хлібців.

Встановлено, що вживання в їжу екструзійних продуктів (хлібці 1, 2, 3) не чинить негативного впливу на загальний стан, вид волосяного покриву, поведінкові реакції лабораторних тварин.

Порівняльні клінічні лабораторні випробування як на невагітних, так і на вагітних щурах та самках-годувальницях Wistar показали, що тривале введення в раціон досліджених видів екструзійних продуктів протягом 30 діб не викликає патологічних порушень ваги тварин, не впливає на індекси внутрішніх органів (серце, печінка, нирки, селезінка) (табл. 1, 2).

Таблиия 1. Відносна маса органів невагітних щурів-самиць Wistar після 30 діб споживання екструзійних продуктів

\begin{tabular}{|l|c|c|c|c|}
\hline \multirow{2}{*}{$\begin{array}{c}\text { Група тварин, } \\
\text { n=5 }\end{array}$} & \multicolumn{4}{|c|}{ Відносні коефіціснти маси внутрішніх органів,\%, (M $\pm \mathrm{SD})$} \\
\cline { 2 - 5 } & серце & печінка & селезінка & нирки \\
\hline Контроль & $2,77 \pm 0,36$ & $32,38 \pm 1,89$ & $1,85 \pm 0,36$ & $5,01 \pm 0,35$ \\
\hline Хлібці 1 & $2,87 \pm 0,32$ & $31,29 \pm 2,40$ & $1,99 \pm 0,28$ & $4,97 \pm 0,36$ \\
\hline Хлібці 2 & $2,98 \pm 0,40$ & $30,38 \pm 3,31$ & $2,01 \pm 0,35$ & $5,54 \pm 0,62$ \\
\hline Хлібці 3 & $2,75 \pm 0,41$ & $32,34 \pm 3,92$ & $1,79 \pm 0,48$ & $5,50 \pm 0,42$ \\
\hline
\end{tabular}


Таблиия 2. Відносна маса органів щурів-самиць Wistar після пологів і періоду вигодовування новонароджених після 30 діб споживання екструзійних продуктів

\begin{tabular}{|l|c|c|c|c|}
\hline \multirow{2}{*}{$\begin{array}{c}\text { Група тварин, } \\
\text { n=5 }\end{array}$} & \multicolumn{3}{|c|}{ Відносні коефіцієнти маси внутрішніх органів,\%, (M $\pm \mathrm{SD})$} \\
\cline { 2 - 5 } & серце & печінка & селезінка & нирки \\
\hline Контроль & $3,45 \pm 0,47$ & $35,02 \pm 2,30$ & $2,26 \pm 0,03$ & $5,86 \pm 0,70$ \\
\hline Хлібці 1 & $3,77 \pm 0,69$ & $37,41 \pm 7,94$ & $1,84 \pm 0,34$ & $5,93 \pm 0,53$ \\
\hline Хлібці 2 & $3,08 \pm 0,55$ & $33,93 \pm 3,03$ & $1,63 \pm 0,45$ & $5,02 \pm 0,29$ \\
\hline Хлібці 3 & $3,01 \pm 0,21$ & $31,64 \pm 4,30$ & $1,84 \pm 0,39$ & $5,41 \pm 0,26$ \\
\hline
\end{tabular}

Встановлено відсутність шкідливої дії тривалого вживання досліджуваних продуктів харчування на гемопоез і властивості крові. Оцінка біохімічних показників крові показала позитивний вплив на нормалізацію обмінних процесів в організмі.

На підставі проведених досліджень виявлено, що групи тварин, які отримували екструзійні продукти - хлібці 1, 2, 3, відрізнялися низьким значенням глікемічного індексу.

У самиць щурів (невагітних і вагітних), що піддавалися харчовій депривації в експерименті, мінімальні показники рівня глюкози в крові на тлі позбавлення їжі досягали 4,8 ммоль/л, а максимальні - 5,3 ммоль/л, що відповідає фізіологічним нормам [7].

Встановлено, що у тварин, як невагітних, так і вагітних, які отримували екструзійні продукти хлібці 1, 2, 3, приріст глікемії був нижчим порівняно з контрольними групами (рис. 1, 2).

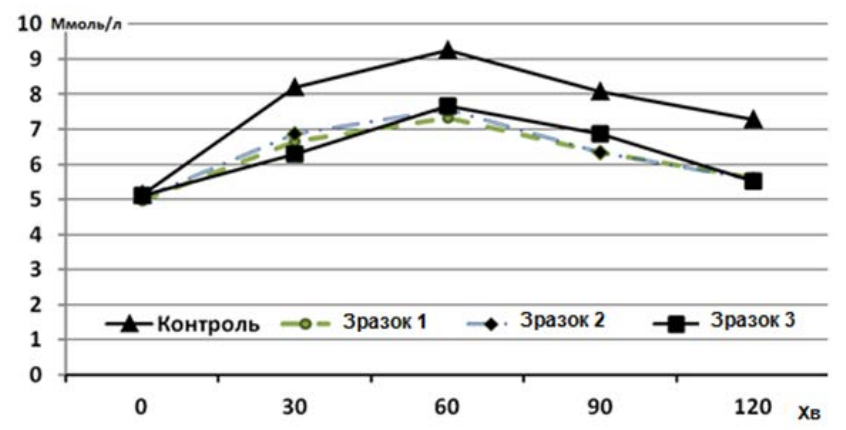

Рис. 1. Зміна рівня глюкози в крові тварин (невагітних самиць щурів Wistar) при споживанні екструзійних продуктів протягом 15 діб: зразок 1 - хлібці 1, зразок 2 - хлібці 2 , зразок 3 - хлібці 3

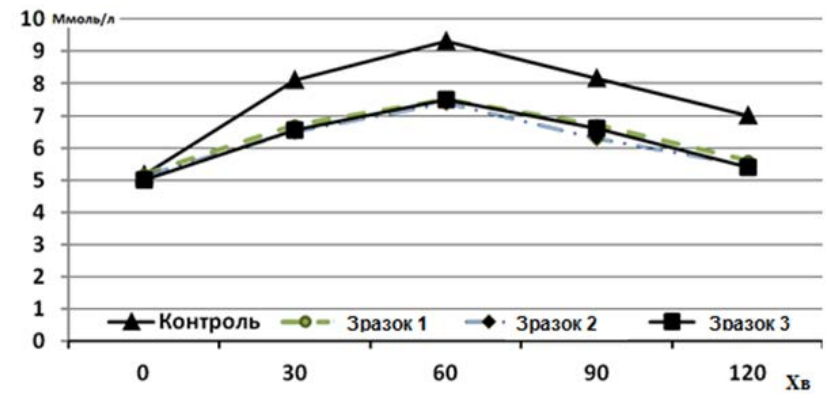

Рис. 2. Зміна рівня глюкози в крові тварин (вагітних самиць щурів Wistar) при споживанні екструзійних продуктів протягом 15 діб: зразок 1 - хлібці 1 , зразок 2 - хлібці 2, зразок 3 - хлібці 3 
У табл. 3 і 4 представлені розраховані відносні глікемічні індекси досліджуваних зразків.

Таблиия 3. Відносний глікемічний індекс досліджуваних екструзійних продуктів при вживанні в їжу невагітними самицями щурів Wistar до 15 діб експерименту

\begin{tabular}{|l|c|c|}
\hline Група тварин, $\mathrm{n}=5$ & $\begin{array}{c}\text { Інтеграл } \\
\text { (площі кривої) }\end{array}$ & Глікемічний індекс \\
\hline Контроль & 6520 & 100,0 \\
\hline Хлібці 1 & 3707 & $56,94 \pm 0,84$ \\
\hline Хлібці 2 & 3518 & $54,20 \pm 2,87$ \\
\hline Хлібці 3 & 3376 & $52,12 \pm 0,28$ \\
\hline
\end{tabular}

Таблиця 4. Відносний глікемічний індекс досліджуваних екструзійних продуктів при вживанні в їжу вагітними самицями щурів Wistar до 15 діб експерименту

\begin{tabular}{|l|c|c|}
\hline Група тварин, $\mathrm{n=5}$ & $\begin{array}{c}\text { Інтеграл } \\
\text { (площі кривої) }\end{array}$ & Глікемічний індекс \\
\hline Контроль & 6479 & 100,0 \\
\hline Хлібці 1 & 3425 & $53,38 \pm 2,77$ \\
\hline Хлібці 2 & 2950 & $50,02 \pm 1,67$ \\
\hline Хлібці 3 & 2825 & $51,67 \pm 1,62$ \\
\hline
\end{tabular}

Проведені розрахунки дають змогу зробити висновок про те, що всі досліджувані зразки екструзійних продуктів можна віднести до продуктів з низьким глікемічним індексом. Найкращим ефектом впливу володіли хлібці 2 i 3 з найменшим глікемічним індексом.

Зроблений висновок узгоджується 3 низкою рекомендацій з харчування, в яких значення $\geq 70$ характеризують продукти з високим, 55-69- середнім - i $\leq 55-$ низьким глікемічним індексом.

Одним із показників, що свідчать про стан вуглеводного обміну, є коефіцієнт Бодуена, або гіперглікемічний коефіцієнт, - відношення вмісту глюкози через 30 хв (береться найбільша величина) до іiі рівня натще (у нормі не вище 1,7). Стан вуглеводного обміну і величини коефіцієнта Бодуена в усіх вивчених групах тварин відповідали фізіологічним значенням (табл. 5, 6) [8].

Таблиця 5. Гіперглікемічний коефіціснт досліджуваних екструзійних продуктів при вживанні в їжу невагітними самицями щурів Wistar до 15 діб експерименту

\begin{tabular}{|l|c|}
\hline \multicolumn{1}{|c|}{ Група тварин, $\mathrm{n}=5$} & Гіперглікемічний коефіцієнт \\
\hline Контроль & $1,59 \pm 0,01$ \\
\hline Хлібці 1 & $1,34 \pm 0,02$ \\
\hline Хлібці 2 & $1,36 \pm 0,01$ \\
\hline Хлібці 3 & $1,23 \pm 0,04$ \\
\hline
\end{tabular}

Таблиця 6. Гіперглікемічний коефіціснт досліджуваних екструзійних продуктів при вживанні в їжу вагітними самицями щурів Wistar до 15 діб експерименту

\begin{tabular}{|l|c|}
\hline \multicolumn{1}{|c|}{ Група тварин, $\mathrm{n}=5$} & Гіперглікемічний коефіцієнт т \\
\hline Контроль & $1,57 \pm 0,03$ \\
\hline Хлібці 1 & $1,31 \pm 0,02$ \\
\hline Хлібці 2 & $1,28 \pm 0,01$ \\
\hline Хлібці 3 & $1,30 \pm 0,01$ \\
\hline
\end{tabular}


Висновки. Отримані дані дають змогу оцінити вивчені екструзійні продукти як безпечні та рекомендувати хлібці екструзійні, збагачені кальцієм, хлібці екструзійні безсольові і хлібці екструзійні з інуліном, що володіють низьким глікемічним індексом, для дієтичного харчування вагітних і жінок-годувальниць та для інших категорій населення.

\title{
ЛІТЕРАТУРА
}

1. Липатов Н. Н. Методология проектирования продуктов питания с необходимым комплексом показателей пищевой ценности М. М. Липатов, И. А. Рогов // Известия вузов. Серия “Пищевая технология”. - 1987. — № 2. - С. 9-15.

2. Георгиева А. В. Проблемы оптимизации питания беременных и кормящих женщин и роль специализированных молочных продуктов отечественного производства / А. В. Георгиева, М. В. Гмошинская // вопросов. детской диетологии. - 2007. — Т. 5, № 4. - C. 15-20.

3. Спиричев В. Б. Медико-биологические подходы к разработке специализированных продуктов питания для беременных и кормящих женщин / В. Б. Спиричев [и др]. // вопросов. детской диетологии. — 2005. - Т. 3, № 3. - С. 41-47.

4. Концепция государственной политики в области здорового питания населения Республики Беларусь на период до 2020 года. — Минск, 2015.

5. Dorrel D. G. Irrigation, fertilizer, har vest dates and storage effects on the reducing sugar and fructose concentrations of Jerusalem artichocke tubers / D. G. Dorrel, B. B. Chubey // Can J. Plant Sci. — 2007. — № 57. - P. 591 - 596.

6. Williams C. M. Inulin and oligofructose: effects on lipid metabolism from human studies / C. M. Williams, K. G. Jackson // Br. J. Nutr. — 2008. — Vol. 87. — Suppl. 2. — P. 261-264.

7.Селятицкая В. Г. Активность адренокортикальной системы у крыс с высокой и низкой устойчивостью к диабетогенных действия аллоксана / В. Г. Селятицкая, Н. А. Пальчиковая, Н. В. Кузнецова // Фундаментальные исследования. — 2011. — № 3. - С. 142-147.

8. Волчегорский И. А. Инсулинпотенциююча действие антиоксидантов при экспериментальном сахарном диабете / И. А. Волчегорский, Л. Рассохина, И. Ю. Мирошниченко / / Проблемы эндокринологии. - 2010. —№ 2. - С. 27-35.

\section{БИОЛОГИЧЕСКИЕ ИССЛЕДОВАНИЯ СПЕЦИАЛИЗИ- РОВАННЫХ ЭКСТРУЗИОННЫХ ПРОДУКТОВ ДЛЯ БЕРЕМЕННЫХ И КОРМЯЩИХ ЖЕНЩИН}

\author{
Н. С. Лаптенок \\ Государственное предприятие «Белтехнохлеб», г. Минск, Республика \\ Беларусь \\ Е. М. Тумар, В. В. Лапцевич \\ Институт биоорганической химии НАН Беларуси, г. Минск, Республика \\ Беларусь \\ Л. А. Мельникова, канд.биол.н. \\ УО «Белорусский государственный экономический университет», г. Минск, \\ Республика Беларусь
}

В статье рассмотрена важность специализированного питания для здоровья беременных и кормящих женщин и представлены результаты исследований влияния новых видов экструзионных изделий на организм беременных и небеременных крыс. Изучение гематологических и биохимических параметров, гликемического индекса показало безопасность и эфффективность используемых продуктов.

Ключевые слова: экструзионные продукты, гликемический индекс, питание беременных женщин. 